\title{
Blending field observations and AWRA outputs to estimate groundwater recharge in the Clarence-Moreton basin, eastern Australia
}

\author{
$\underline{\text { R. Crosbie }}{ }^{a}$, M. Raiber ${ }^{b}$, T. Cui ${ }^{b}$ and N. Viney \\ ${ }^{a}$ CSIRO Land and Water, Waite Campus, South Australia \\ b CSIRO Land and Water, Dutton Park, Queensland \\ ${ }^{c}$ CSIRO Land and Water, Black Mountain, Australian Capital Territory \\ Email: russell.crosbie@csiro.au
}

\begin{abstract}
Groundwater recharge is one of the hardest components of the water balance to estimate, largely because it cannot be directly measured. The Landscape component of the Australian Water Resources Assessment model (AWRA-L), has been shown to have the capacity to reproduce the temporal trends of groundwater recharge when compared to time series of field data at a limited number of locations. However, it cannot reproduce the heterogeneity in long term average recharge at a local scale. Many of our field techniques for estimating recharge can only produce a long term average recharge rate and provide no information on temporal variations. Blending the long term average recharge estimates from field observations with the continuous daily output of the AWRA-L model allow us to create a time series of recharge that honours the long term average of field observations whilst imposing the modelled temporal patterns.

The Clarence-Morton Basin straddles the Qld-NSW border east of the Great Dividing Range and is one of the regions currently being studied as part of the Bioregional Assessments Programme. The majority of the basin has had limited investigations of its groundwater recharge processes with no knowledge of the long term average recharge rates and their inter-annual variabilities. Upon adoption of the chloride mass balance method for estimating recharge, 374 point estimates of recharge were obtained for this basin. These were subsequently used to create regression equations between the average annual recharge and the average annual rainfall for each of the surface geology types in the basin; this enabled those point estimates to be upscaled to the basin scale. The temporal pattern from AWRA-L was then imposed for each grid cell in the landscape to create a annual time series of recharge across the entire basin.

The results of this investigation showed that the Walloon Coal Measures had the lowest annual average recharge rate (for a given rainfall) and the tertiary volcanics had the highest. The temporal trends in recharge from AWRA-L were similar between surface geology types with wet years having above average recharge and dry years having below average recharge. These results form an essential input into the numerical groundwater model used to investigate the impact of coal seam gas extraction upon water dependent assets in the Richmond River catchment, NSW.
\end{abstract}

Keywords: AWRA, recharge, WIRADA, bioregional assessments 


\section{INTRODUCTION}

Quantification of groundwater recharge is one of the hardest components of the water balance largely because it cannot be directly measured. The Landscape component of the Australian Water Resources Assessment model (AWRA-L; Vaze et al., 2015) has been shown to have the capacity to reproduce the temporal trends of groundwater recharge when compared to time series field data at a limited number of locations, however, it cannot reproduce the heterogeneity in long term average recharge at a local scale (Shi et al., 2015). Many of the field techniques for estimating recharge can only produce a long term average recharge rate with no information on temporal variations. Blending the long term average recharge estimates from field observations with the continuous daily output of the AWRA-L model allow us to create a time series of recharge that honours the long term average of the field observations whilst imposing the modelled temporal patterns.

\section{STUDY AREA}

The Clarence-Morton Basin straddles the Qld-NSW border east of the Great Dividing Range and is one of the regions currently being studied as part of the Bioregional Assessments Programme (Rassam et al., 2014). The majority of the basin has had limited investigations of its groundwater recharge processes with no knowledge of the long term average recharge rate and their inter-annual variabilities.

\section{METHODS}

\subsection{AWRA estimates of recharge}

The AWRA-L model is a landscape model that is capable of producing many water balance components (runoff, recharge, ET, soil moisture etc.) on a daily time step at a $0.05^{\circ}(\sim 5 \mathrm{~km})$ spatial resolution. It has conventionally been used to estimate runoff but is now being used to report more elements of the water balance including recharge. The model has been calibrated to all available stream gauges in the vicinity of the Richmond River catchment within the Clarence-Morton Bioregion, it is the recharge outputs that are of interest to this study. More details on the calibration of the model are available in Viney et al. (2015). The key determinants in estimating recharge are rainfall, vegetation type and soil type (Crosbie et al., 2010), as these are all spatially explicit inputs into AWRA-L (Viney et al., 2015) it should be able to produce reasonable estimates of recharge.

\subsection{Point estimates of recharge}

Dryland diffuse groundwater recharge is a necessary input into numerical groundwater models, that is, groundwater recharge due to rainfall (as opposed to recharge due to irrigation drainage or stream losses). There have not been previous recharge estimates made in the Clarence-Morton Bioregion at a scale suitable for the numerical groundwater model being built for this region, and hence the recharge estimates being made here. The chloride mass balance method of Anderson (1945) is the most widely used method for estimating recharge in Australia (Crosbie et al., 2010), this is due to the availability of data that underpins it, its simplicity and cost effectiveness.

The assumptions behind the chloride mass balance are that (Wood, 1999):

1. Chloride in groundwater is sourced from rainfall (not from rock weathering or interactions with streams or deeper aquifers)

2. Chloride is conservative in the system (no sources or sinks)

3. The chloride flux does not change over time (steady state conditions)

4. There is no recycling of chloride in the system (e.g., due to irrigation drainage)

If these conditions can be met, then recharge is estimated as follows:

$$
R=\frac{100 D}{\left[C l^{-}\right]_{g w}}
$$

where the recharge (R) is in $\mathrm{mm} / \mathrm{yr}$, the chloride deposition (D) is in $\mathrm{kg} / \mathrm{ha} / \mathrm{yr}$, and the chloride concentration of groundwater $\left[\mathrm{Cl}^{-}\right]_{\mathrm{gw}}$ is in $\mathrm{mg} / \mathrm{L}$. 
The chloride deposition over the Clarence-Morton Bioregion extracted from the national dataset at a resolution of $0.05^{\circ}$ (Leaney et al., 2011) shows chloride deposition to be much greater near the coast compared to inland areas (Figure 1). There were about 4000 points with chloride data available within the bioregion boundaries, which were assigned to an aquifer based on the screen location (Figure 1). Additional chloride originating from streams as well as upward flow from deeper aquifers deemed this method to be inadequate for estimating recharge in alluvial areas. Similarly, recharge could not be estimated in situations where the screen was not in the same aquifer as the surface geology due to potential leakage from the overlying formations. Consequently, there were only 374 valid point estimates of recharge, which were not uniformly distributed across the spatial extent of the bioregion (Figure 1).
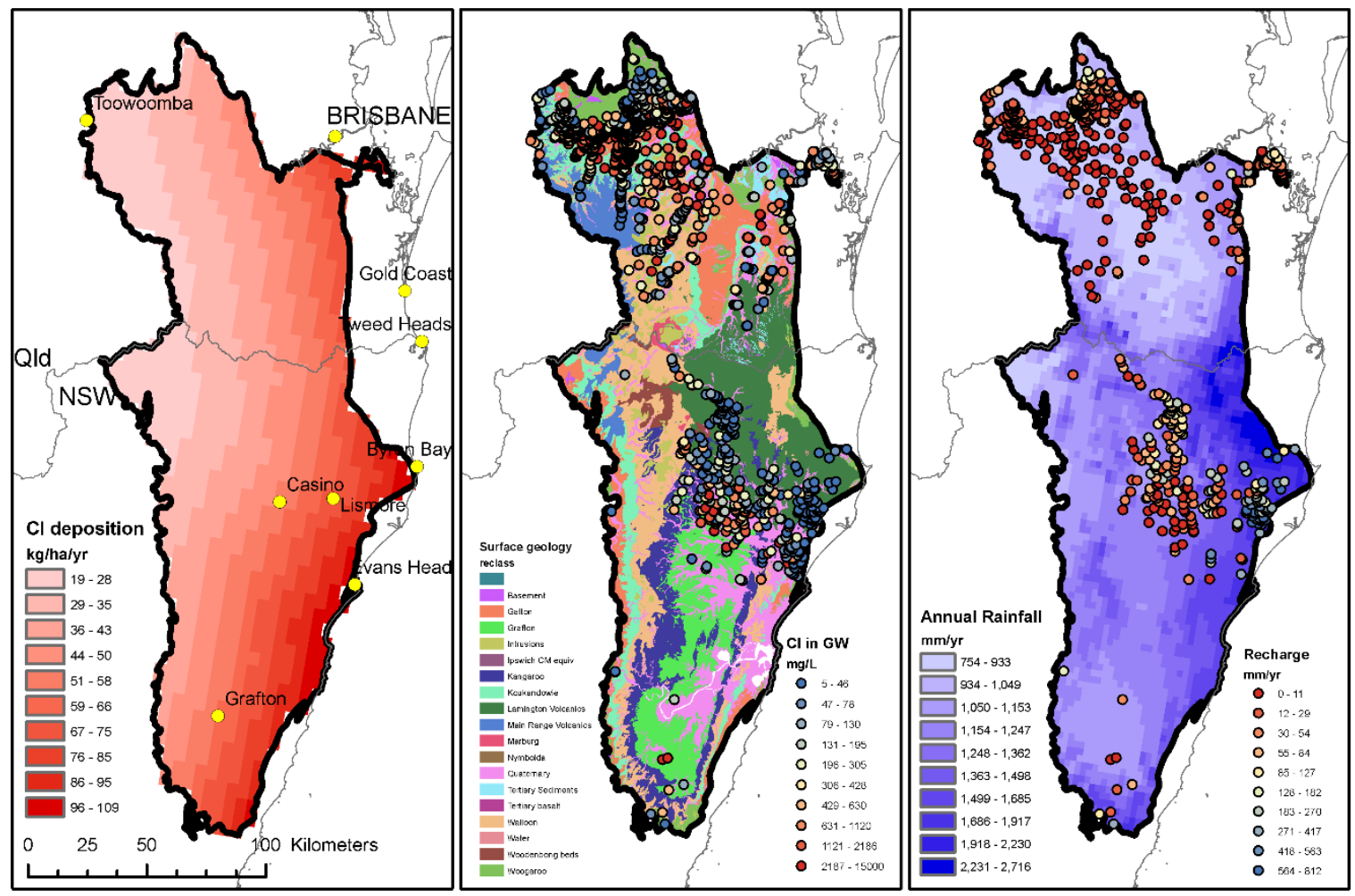

Figure 1. Inputs into the CMB method. Left panel showing the chloride deposition, centre panel showing the chloride concentration of the groundwater over the surface geology type and the right panel showing the annual average rainfall and the point estimates of recharge (excluding points on alluvium).

\subsection{Upscaling point estimates of recharge}

As numerical models require a continuous surface of recharge estimates, the point estimates derived from the chloride mass balance method needed to be up-scaled. It has been shown by (Crosbie et al., 2010) that annual average rainfall, soil type and vegetation type are the key determinants of recharge and had been previously used to upscale point estimates (Crosbie et al., 2013). However, the paucity of data in this region led to using annual average rainfall across three different classes of surface geology as co-variates. Those classes were chosen on the basis that: tertiary volcanics have higher recharge rates for a given rainfall compared to other rock types; Walloon Coal Measures are of interest as their outcrop areas recharge and replenish the aquifer following the cessation of CSG pumping; all other rock types were lumped together due to a lack of data needed to distinguish between them.

A log-linear relationship was adopted for estimating annual average recharge from annual average rainfall, this is similar to relationships developed previously from both field and modelled data (Crosbie et al., 2013; Crosbie et al., 2010). At the higher end of the rainfall spectrum (especially when extrapolated beyond the range of the field data), the log-normal relationship can predict recharge rates that are much greater than rainfall. To prevent 
this happening, a global maximum recharge rate equal to half the rainfall has been imposed, this is approximately the highest recharge estimated from the point scale chloride mass balance estimates. As the chloride mass balance method was not appropriate for alluvial areas, empirical relationships developed from historical field data to predict recharge using average annual rainfall, soil clay content and vegetation were alternatively implemented (Wohling et al., 2012).

\subsection{Temporal scaling of upscaled recharge estimates}

The upscaled estimates of recharge from the chloride mass balance provided a long term average recharge rate whereas the AWRA-L model provided a credible temporal sequence of recharge, these two need to be combined. The AWRA-L outputs have been aggregated at the grid cell scale to create an annual series of recharge, which was then normalised (Figure 2) (subtract the mean and divide by the standard deviation). As the normalised annual series of recharge is similar for all grid cells, a single normalised annual series was created by averaging across all grid cell (red line in Figure 2). Together with the average coefficient of variation (standard deviation divided by the mean) across all grid cells, the annual series of normalised recharge can then be used to scale the upscaled long term average recharge from the chloride mass balance into a spatially explicit annual series of recharge.
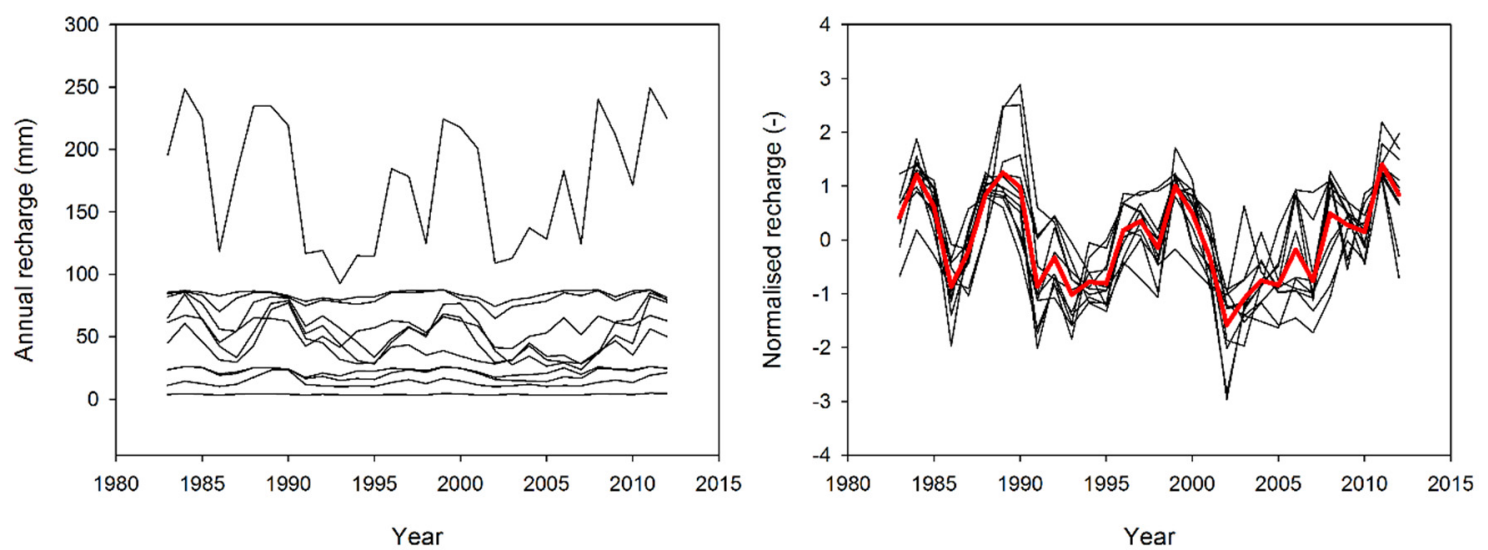

Figure 2. Example of the annual series of recharge from the AWRA model for 11 randomly selected grid cells (left). The same 11 annual series after having been normalised with the mean shown in red (right). (These 11 grid cells are used as an example for the figure, if all 341 grid cells were displayed the figure would not be clear).

\section{RESULTS}

The point scale estimates of recharge are shown in Figure 1, it can be seen that they are spread unevenly through throughout the basin. To get a spatially continuous estimate of recharge upscaling is necessary. Regression equations have been developed between the point scale average annual rainfall and the annual average recharge for three classes of surface geology (Figure 3). It can be seen that for a given amount of rainfall the tertiary volcanics class has a higher recharge than the Walloon Coal Measures, the third class is an amalgamation of all other surface geology types and lies between the other two classes. 

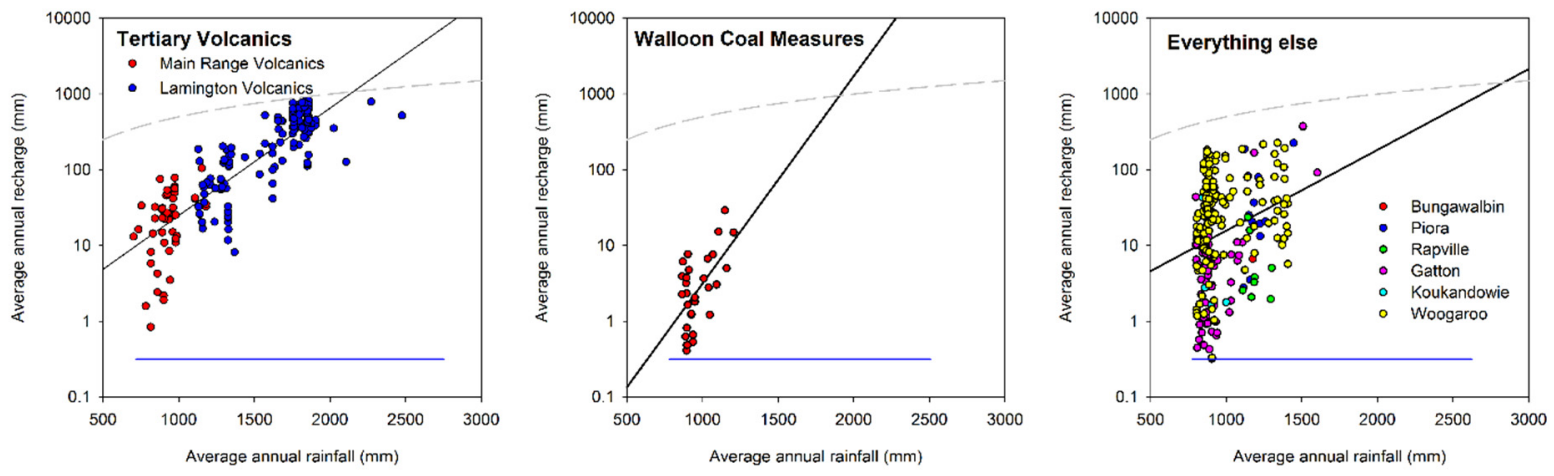

Figure 3. Relationship between annual average rainfall and annual average recharge for three groupings of surface geology. The black line is the line of best fit through the data points, the dashed grey line is recharge as half of rainfall and the blue line is the range of annual average rainfall within the bioregion for the surface geology class.

These regression equations were then used to estimate recharge spatially using the annual average rainfall (Figure 1) as a co-variate. The upscaled annual average recharge is shown in Figure 4. This shows that the highest recharge is in the east of the bioregion where rainfall is highest on the tertiary volcanics and alluvium with the recharge greatly reduced inland. The average areal recharge across the entire bioregion is $116 \mathrm{~mm} / \mathrm{yr}$.

The average annual recharge estimated from AWRA-L is at a much coarser scale than the upscaled recharge estimates from the chloride mass balance $(\sim 5 \mathrm{~km}$ cf. $100 \mathrm{~m}$ grid). Figure 4 shows the contrasting estimates of recharge provided by the two methods. In addition to differences in scale, the magnitude of annual average recharge is also differernt; AWRA-L estimates areal average recharge to be $27 \mathrm{~mm} / \mathrm{yr}$ over the entire model domain whereas the upscaled chloride mass balance estimate is $72 \mathrm{~mm} / \mathrm{yr}$ over the same area.

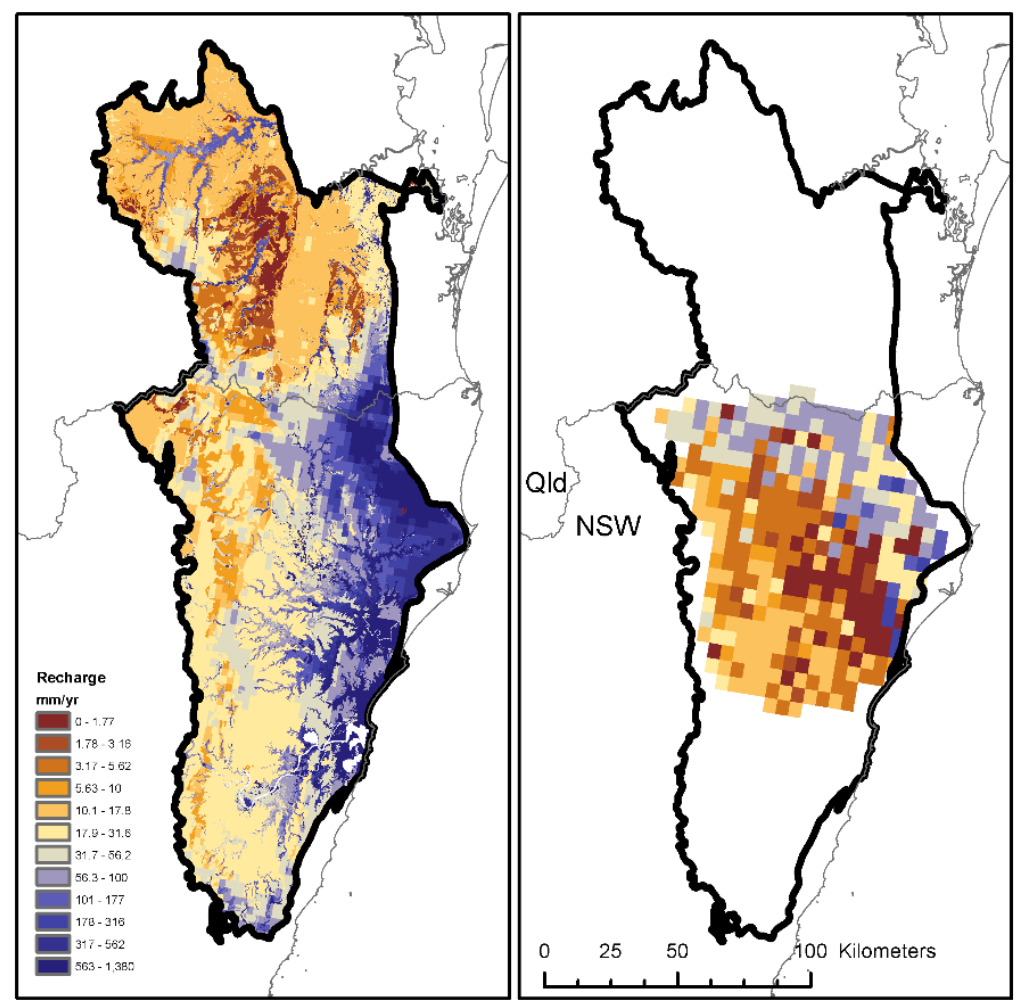

Figure 4. Upscaled estimates of annual average recharge over the bioregion (left) and the annual average recharge outputs from AWRA over the numerical model domain (right).

As we wish to maintain the spatial pattern of the long term average recharge derived from the upscaled chloride mass balance estimates of recharge and use the temporal pattern from the AWRA-L model, further scaling is necessary. The temporal pattern for each grid cell in AWRA-L was averaged to produce a single annual series 
that was stamped over each grid cell in the upscaled chloride mass balance estimates of recharge. The results are shown in Figure 5 with the minimum annual areal recharge of $79 \mathrm{~mm}$ occurring in 2002 and the maximum of $148 \mathrm{~mm}$ occurring in 2011.
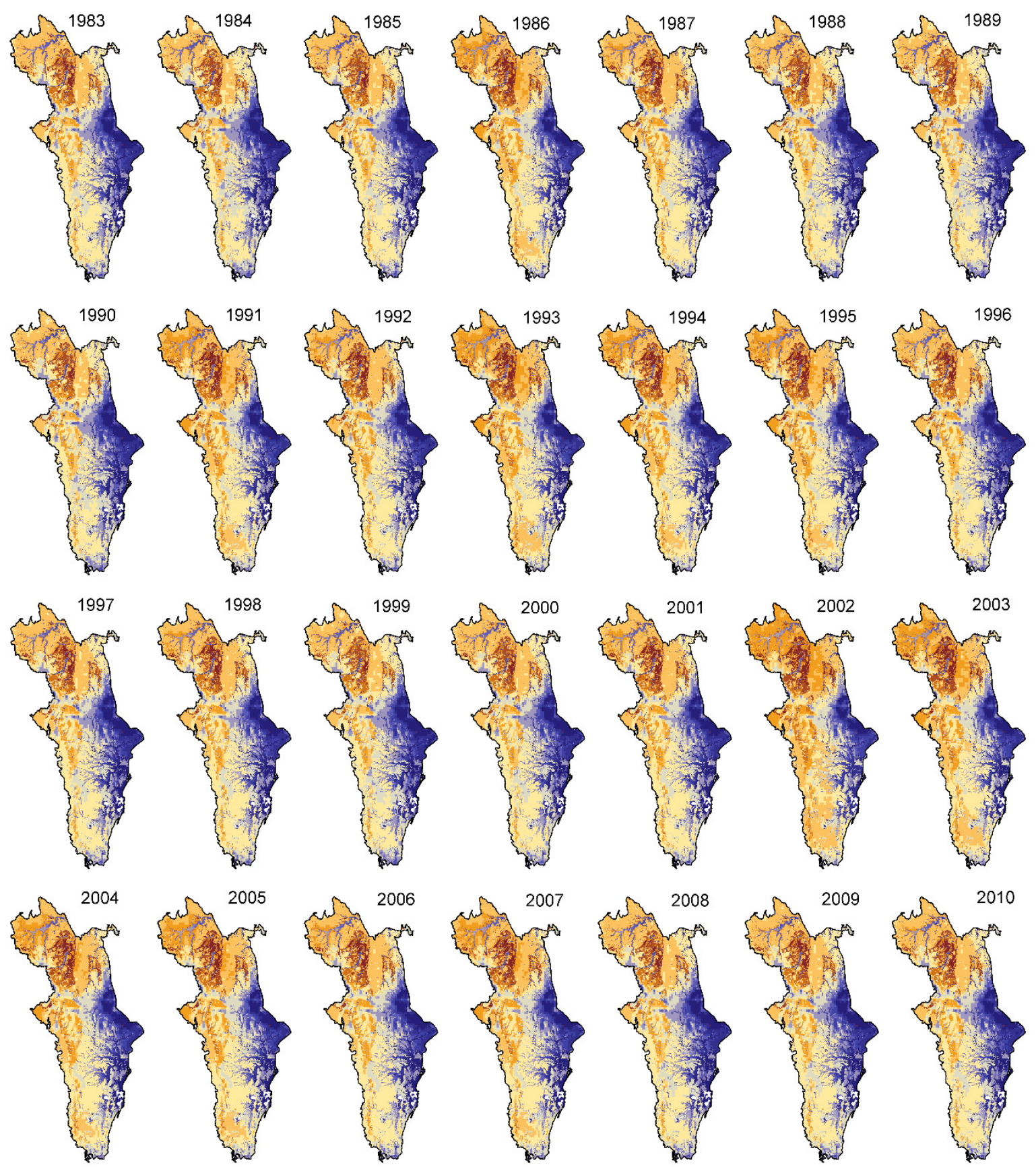

Figure 5. Annual series of spatial recharge across the Clarence-Morton basin. Colour scale is the same as Figure 4.

\section{DISCUSSION AND CONCLUSIONS}

This study has provided spatially continuous estimates of long term average groundwater recharge across the entire Clarence-Morton Basin derived from upsacled chloride mass balance estimates of recharge that were subsequently disaggregated into an annual series using the outputs of the landscape model AWRA-L. The resultant annual series of recharge is in a form and at a resolution consistent with the requirements of numerical groundwater flow models. 
The uncertainty in recharge estimates made here correspond to violations of the underpinning assumptions of the chloride mass balance method. For example, b neglecting the chloride that is lost from the system through surface runoff leads to an overestimation of recharge, whereas failing to account for the enhanced deposition on forested areas leads to underestimating recharge. The assumption of steady state that is violated in areas that have been cleared of native vegetation for agriculture alsoleads to an underestimation of recharge.

\section{ACKNOWLEDGEMENTS}

This work is funded by the Water Information Research and Development Alliance (a collaboration between CSIRO and the Bureau of Meteorology) and the Bioregional Assessment Programme (a collaboration between Department of the Environment, Bureau of Meteorology, CSIRO and Geoscience Australia).

\section{REFERENCES}

Anderson VG (1945) Some effects of atmospheric evaporation and transpiration on the composition of natural water in Australia (continued). 4. Underground waters in riverless areas. J. Aust. Chem. Inst 12, 8398.

Crosbie R, Pickett T, Mpelasoka F, Hodgson G, Charles S and Barron O (2013) An assessment of the climate change impacts on groundwater recharge at a continental scale using a probabilistic approach with an ensemble of GCMs. Climatic Change 117, 41-53. DOI: 10.1007/s10584-012-0558-6.

Crosbie RS, Jolly ID, Leaney FW and Petheram C (2010) Can the dataset of field based recharge estimates in Australia be used to predict recharge in data-poor areas? Hydrology and Earth System Sciences 14(10), 2023-2038. DOI: 10.5194/hess-14-2023-2010.

Leaney F, Crosbie R, O’Grady A, Jolly I, Gow L, Davies P, Wilford J and Kilgour P (2011) Recharge and discharge estimation in data poor areas: Scientific reference guide. CSIRO: Water for a Healthy Country National Research Flagship.

Rassam D, Raiber M, McJannet D, Janardhanan S, Murray J, Gilfedder M, Cui T, Matveev V, Doody T, Hodgen M and Ahmad M (2014) Context statement for the Clarence-Moreton bioregion. Product 1.1 from the Clarence-Moreton Bioregional Assessment. . Department of the Environment, Bureau of Meteorology, CSIRO and Geoscience Australia, Australia.

Shi X, Crosbie R and Vaze J (2015) Long-term trends in the annual groundwater recharge estimates from the water table fluctuation method. MODSIM 2015.

Vaze J, Dutta D, Crosbie R, Viney N, Penton D, Teng J, Wang B, Kim S, Hughes J, Yang A, Vleeshouwer J, Peeters L, Ticehurst C, Shi X, Dawes W, Hafeez M and Frost A (2015) An integrated continental hydrological modelling system - AWRA. MODSIM 2015.

Viney $\mathrm{N}$ and et al. (2015) Surface water numerical modelling for the Clarence-Moreton bioregion. Product 2.6.1 for the Clarence-Morton Bioregional Assessment. Department of the Environment, Bureau of Meteorology, CSIRO and Geoscience Australia, Australia.

Viney N, Vaze J, Crosbie R, Wang B, Dawes W and Frost A (2015) AWRA-L v5.0: technical description of model algorithms and inputs. CSIRO, Australia.

Wohling DL, Leaney FW and Crosbie RS (2012) Deep drainage estimates using multiple linear regression with percent clay content and rainfall. Hydrol. Earth Syst. Sci. 16(2), 563-572. DOI: 10.5194/hess16-563-2012.

Wood WW (1999) Use and misuse of the chloride-mass balance method in estimating ground water recharge. Ground Water 37(1), 2-3. 